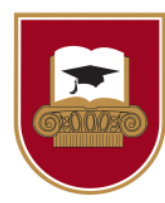

Vadyba

Journal of Management

2020, № 1 (36)

ISSN 1648-7974

\title{
THE BEST TRAITS OF ENTREPRENEURS: A RESEARCH ON THE PARTICIPANTS OF ENTREPRENEURSHIP TRAINING PROGRAMS
}

\author{
Kurtuluş Yılmaz Genç \\ Giresun University, Turkey
}

\begin{abstract}
The aim of this study is to put forth the framework of the estimated traits of entrepreneurs. As, success requires special traits in any job, or in any professional area, entrepreneurship requires many special traits. This study depends on a literature review, and a research which was conducted on the participants of official entrepreneurship training programs in Turkey, about the estimated traits of entrepreneurs. The data analysis has shown that, self-confidence, innovativeness, honesty, risk taking, ability for marketing, sense of responsibility, leadership, creativity, determination, utilizing the opportunities are the top traits that the participants linked with the entrepreneurs. On the other hand, independent decision making, change focus, emotional intelligence, proactivity, and flexibility against uncertainty are the least traits that were associated by the participants with entrepreneurship. Also, it was found that gender, age, and the number of children in the family are statistically significantly associated with the preferences of respondents about the best traits of entrepreneurs.

KEY WORDS: Entrepreneurship traits, Entrepreneurship training programs, Turkey, Culture.
\end{abstract}

\section{Introduction}

As, success requires special traits in any job, or in any professional area, entrepreneurship requires many special traits. These traits can be the self-confidence, innovativeness, honesty, risk taking, ability for marketing, sense of responsibility, leadership, creativity, determination, utilizing the opportunities, communication skill, managerial skill, knowledge, social being, consistency and to be principled, being ambitious, competitiveness, self-check, achievement need, independent decision making, change focus, emotional intelligence, proactivity, and flexibility against uncertainty. Again, more and more traits can be added to these elements.

In the related literature, there are many studies which examined the traits of entrepreneurs. These studies are made in different countries, in different cultures. Although the heterogeneity of literature is stressed (Kerr, Kerr, and Xu 2017), very similar, even same traits are identified for entrepreneurs. This result shows how common it is as a topic for different countries, for different societies, or for different cultures. In addition, it is an indication of the integration of economies, and cultures. On the other hand, many times, researchers test the same dimensions or variables in different researches. The common literature of entrepreneurship also unifies the bases for investigations.

The entrepreneurs of different sectors can have different characteristics (Abdulwahab and Al-Damen 2015; Pirnar 2015). The culture of society, or the culture of each profession can have an impact on the traits of entrepreneurs (Aytaç and İlhan 2020; Çetinkaya Bozkurt, Kalkan, Koyuncu, Alparslan 2012; Pirnar 2015; Salamzadeh, Farjadian, Amirabadi, and Modarresi 2014); even religion can change the perspectives (Nair and Pandey 2006). Moreover, entrepreneurship education can change the views of potential entrepreneurs (Çetinkaya Bozkurt, and Alparslan 2013; Yüceol 2018).

The country practices of entrepreneurship can be different. Accordingly, national characteristics might have impacts on entrepreneurial traits, and entrepreneurial behaviour (Mongia 2013). The differences of entrepreneurial traits can also be in relation with gender (Güney 2006; Yelkialan 2006), age, and personality (Kozubikova, Dvorsky, Cepel, and Balcerzak 2017; Nair and Pandey 2006). In addition, technical education/training, and work experience can support entrepreneurial behaviour (Nair and Pandey 2006).

This study was designed to put forward the views of official entrepreneurship training programs' participants on the topic of 'the traits of entrepreneurs'. The related field research was made through asking the participant the following question: "Which of the five of those 24 traits of entrepreneurs are more important than others for you?" A survey form was used to obtain the data.

This study includes a literature review, and the results of a field research about the estimated traits of entrepreneurs. First, the literature is reviewed, then, the results of the field research is given. This study ends with a conclusion.

\section{Literature Review: The Traits of Entrepreneurs}

The entrepreneurship is one of the main factors that determines the development level, or the wealth of nations. Accordingly, when the experiences or the development history of nations analysed, it can be seen that, entrepreneurship is the key activity which dominates the process. To put it more simply, profit focus, innovativeness, risk taking, and opportunity seeking support societies to accomplish their visions.

Entrepreneurship can be seen as a function of both personality characteristics and situational circumstances or social conditions (Lachman, 1980). 
The entrepreneurial tendency as a function involving three factors closely related to each other. These factors include; (a) the training of entrepreneurship given to the individual, individual's level of accumulated knowledge/background; (b)the beliefs regarding the opportunities and capability to take new risks; and (c)the self-confidence of the individual to recognize and assess the opportunities (Parnell, Crandall, Menefee 1995; Tiftik and Zincirkıran 2014).

Karl Marx defines an entrepreneur as a capitalist, while Schumpeter stresses that, an entrepreneur is a creative transformer (Marx 1867; Tiryaki 2012). So, according to Schumpeter, the human history is an outcome of this creative transformation, or the innovativeness.

Entrepreneurship has many functions: it increases the national income, and so the total demand level that result in a growth in the economy. Again, it stabilizes the economy. The entrepreneurship triggers new start-ups in the same sector, or in related sectors. Moreover, it increases the production level, and differentiates the products. It creates new market segments (Uygun 2016). Finally, entrepreneurship increases the life standards, and the wealth of nations.

There are many approaches to entrepreneurship: psychological, environmental, economic, sociological, personality traits, cognitive, entrepreneurial view, and human capital, firm focused approach. These approaches also explain the origins of characteristics. Accordingly, need for achievement, internal locus of control, risktaking, desire for independence, creativity and innovativeness can be explained in the frame of psychological view. The sociological approach defends that, an entrepreneur should be opportunity oriented, adventurous, ambitious, innovative, pioneer, leader, a top level image creator, and a wider financial strategy implementer (Beaver, 2002).

The individualistic approach explains entrepreneurship with personality traits. These traits should adapt the situation. It can be asserted that, when an entrepreneur is successful, then the basic traits of her or him respond the conditions.

The trait approach links the personality traits with entrepreneurial attitudes, or entrepreneurship. Accordingly, the entrepreneurs have special traits which make them entrepreneurs, and differentiate them from others (Gartner, 1988). This approach points outs that, the most important characteristics of an entrepreneur are as the following: locus of control, need of achievement, risk taking tendency, the need of respect, determination, selfconfidence, desire for independence, being goal focused, being hard working, problem solving, honesty, behaving with responsibility, initiating, human relations skill, rational thinking, and social responsibility behaviour.

The family, the environment, and education affect the formation of entrepreneurial characteristics (Lee 1999). Hence, the environmental approach focuses on environmental characteristics, especially the culture, economic structure, and state policies. Okhomina (2010) found that, a supportive business environment mediates the relationship between psychological traits and entrepreneurial orientation.
The firm approach associates the life cycle of firms with the personality traits of entrepreneurs. Accordingly, the entrepreneur should keep her or his traits as opportunity focused, creative, innovative, and profit aimed.

The cognitive approach focuses on the sources of traits' mental formation. This approach searches, how entrepreneurs benefit from mental models in their business experiences. So, the approach investigates how the representation of comprehension, mental schema, tendencies, cognitive mechanisms, intention, and external environment affect behaviour. This approach defends that, the comprehension of entrepreneurs guide their behaviour, and activities. In addition, the cognitive processes of entrepreneurs differentiate from the cognitive processes of non-entrepreneurs (Baron 1998; Baron 2004; Mitchell et al. 2002).

The entrepreneurial intention approach investigates the sources of entrepreneurial intention. Accordingly, the individual and contextual conditions interact with the rational and intuitional thinking system. Thus, the organization emerges. The contextual conditions includes the social, economic, and political conditions of human; while the individual conditions consist of the experiences, personality, and skills of individual. Initiating a new entrepreneur is a result of rational, analytical, intuitional, result focused and casual thinking process. Entrepreneurial intention transforms into entrepreneurial behaviour. In addition, entrepreneurial intention originates from the attitudes (Whesthead et al. 2003; Uygun 2016).

The human capital approach examines the importance of knowledge, skills, and abilities. This approach argues that, the individuals who have higher levels of knowledge, skills, and abilities will be successful in their business (Becker 1975). The value and rareness of knowledge, skills and abilities might determine the performance levels of entrepreneurs.

An entrepreneur takes the financial, tangible, and psychological risks of establishing a business, and sustains it (Hatten 1997). In the related process, the traits (or the characteristics) of entrepreneurs play a key role to overcome the barriers, and achieve the goals. Megginson, Byrd, and Megginson (2000) stated that, entrepreneurship is a result of the desire for independence, to initiate and complete a process, desire for success, personal causes or causes related with family, the expectation of fast result or fast response, dedication to entrepreneurship, and to start entrepreneurship with a plan.

In the related literature, there are many studies about the traits of entrepreneurs. In these studies, the topic is discussed focusing on different dimensions.

When the literature is reviewed, the most cited entrepreneurial traits merge as the following: creativity and innovativeness (Çetinkaya Bozkurt and Alparslan 2013; Herron 1992; Geisler 1993; Drucker 1998; Daft 2005; Hatten 1997; Hisrich et al. 2005; Hitt et al. 2005; Kerr, Kerr, and $\mathrm{Xu}$ 2017; Lee, 1999); risk taking (Çetinkaya Bozkurt and Alparslan 2013; Geisler 1993; Johnson and Hayes 1996; Drucker 1998; Hatten 1997; Hisrich et al. 2005; Hitt et al. 2005; Zhao et al. 2005; Hewison and Badger, 2006; Kerr, Kerr, and $\mathrm{Xu}$ 2017; Lee, 1999; Salamzadeh, Farjadian, Amirabadi, and 
Modarresi 2014), change focused (Çetinkaya Bozkurt and Alparslan 2013; Luchsinger and Bagby 1987; Herron 1992; Hisrich et al. 2005; Hitt 2005; Kerr, Kerr, and Xu 2017), opportunity focused (Corbett and Hmieleski 2005; Çetinkaya Bozkurt and Alparslan 2013; Hitt et al. 2005), creative (Çetinkaya Bozkurt and Alparslan 2013; Daft, 2005; Hitt et al. 2005; Hewison and Badger, 2006), developed communication skill (Çetinkaya Bozkurt and Alparslan 2013; Hitt et al. 2005; Kerr, Kerr, and Xu 2017), proactivity (Çetinkaya Bozkurt and Alparslan 2013; Hisrich 2005), need for achievement (Çetinkaya Bozkurt and Alparslan 2013; Daft 2005; Kerr, Kerr, and Xu 2017; Salamzadeh, Farjadian, Amirabadi, and Modarresi 2014), emotional intelligence (Çetinkaya Bozkurt and Alparslan 2013; Zakarevicius and Zuperka 2010; Chuluunbaatar and Luh 2010), insist on decisions (Çetinkaya Bozkurt and Alparslan, 2013; Hitt et al. 2005), internal locus of control (Salamzadeh, Farjadian, Amirabadi, and Modarresi 2014).

Specific attitudes lead to successful startups (Mongia, 2013). A general model of entrepreneurship can include the personality, human capital, active performance, and environment dimensions (Kerr, Kerr, and Xu 2017). Personality traits: need for achievement, locus of control, self-efficacy, innovativeness, risk attitude, openness, conscientiousness, extraversion, agreeableness, and neuroticism. Entrepreneurial human capital requires education and training, experience, mental ability, and knowledge. Entrepreneurship also depends on active performance which consists: active goals and visions, active task strategy, active action planning, effectuation, innovation, active social strategy for networking, active feedback seeking, active approach to mistakes, and active approach to learning. The active performance is affected by personality, human capital and environment. The entrepreneurship environment consists of national culture, life cycle, hostility, and industry.

The culture can be an important factor in the formation of entrepreneurial characteristics. Hofstede (1980) tried to identify dimensions of culture by observing the employees of a multinational company IBM that included employees from 40 different countries. He identified and explained the cultural patterns and their differences across different countries. His study involved 5 dimensions such as individualism \& collectivism, masculine and feminine, uncertainty avoidance, power distance and time perspective (long-term or short term orientation).

In individualistic societies, individuals are expected to have loose social ties. They give priority to their individual demands and interests. In other words, individuals in these countries, want to realize their own wishes and desires. They have independen views, and mindset (Triandis and Gelfland 1998). On the contrary, in collectivist societies, individuals have tight social ties and commitments. They give priority to their in-group consisting of their relatives or closest friends. Instead of realizing his own demands and interests, a collectivist individual tries to make his in-group's demands, interest and aims happen. His prior consideration would be his ingroup's interests (Mills and Clark 1982).

The power distance is about interpersonal power or inequality among individuals. The uncertainty avoidance indicates an individual's stance towards the unknown future. Finally, the masculunity dimension measures the division of roles between women and men in a society (Hofstede 1980).

Hofstede (1980) stated that, Turkish culture has the characteristics of high levels of collectivism, power distance, and uncertainty avoidance. On the other hand, the Turkish culture includes moderate feminity.

Çetinkaya Bozkurt (2011) associated entrepreneurial characteristics and culture. The author stressed that, the occurrence of entrepreneurship is related with family, education, culture, personal values, age, gender, work experience, role models, and environment. Similarly, Nair and Pandey (2006) found that, the economic status of the family, age, technical education/training and work experience have links with entrepreneurship. On the other hand, Megginson, Byrd, and Megginson (2000) stress that, an individual can be an entrepreneur in any age.

Guney (2006), and Yelkialan (2006), examined the dimension of gender in entrepreneurship. These scholars focused on the topic of "women entrepreneurship", and stressed that gender differences affect the entrepreneurial practice. Abdulwahab and Al-Damen (2015) found that, there is an impact of entrepreneurs' characteristics on the small business success. Nair and Pandey (2006) identified that, economic status of the family, age, technical education/training, and work experience affect the traits of entrepreneurs. The scholars also achieved the result that, although they are more innovative compared with the rest of people, entrepreneurs do not have faith in the internal locus of control.

Based on the literature given above the following hypotheses are developed:

H1: There is a statistically significant relationship between the age of the respondents and their preference of best entrepreneurial traits.

$\mathrm{H} 2$ : There is a statistically significant association between the professions of the respondents and their preference of best entrepreneurial traits.

H3: The work experiences of respondents are statistically significantly associated with their best entrepreneurial trait preferences.

H4: There is a statistically significant relationship between the number of children that the respondents have and the preference of respondents about the best traits of entrepreneurs.

H5: The thoughts on the best traits of entrepreneurs and the gender are statistically significantly associated.

Kozubikova, Dvorsky, Cepel, and Balcerzak (2017) demonstrated that, entrepreneurs' management of financial risks in their firms is not associated with their age, gender, education, or personality traits. In contrast, they showed that, entrepreneurs' personality traits as "decisiveness", and "optimism" has relationships with their age, and gender. In addition, entrepreneurs' view of the minimization of risk taking through building-up 
reserves is linked with the qualities as "risk taking", and "decisiveness".

Salamzadeh, Farjadian, Amirabadi, and Modarresi (2014) searched on a random sample of undergraduate students of three universities in Iran, majoring in six fields of study. They surveyed to measure and compare their entrepreneurial characteristics which were profiled in the bases of traits: open mindedness, need for achievement, pragmatism, tolerance of ambiguity, visionary, challenge taking, risk taking, and internal locus of control. The scholars have found that, the traits and the fields of study are correlated.

Çetinkaya Bozkurt (2011), expressed the basic traits for entrepreneurs: the need for success, internal locus of control, risk taking orientation, tolerance to ambiguity, self-confidence, innovativeness, and emotional intelligence.

Aytaç and İlhan (X), linked entrepreneurship with the culture of the society. Yüceol (2018), identified relationships between personality traits and entrepreneurial orientation level.

Çetinkaya Bozkurt, Kalkan, Koyuncu, and Alparslan (2012) stressed that, entrepreneurship is a social and cultural event. These scholars identified that, these traits are mostly mentioned by the participants for entrepreneurs: Self-confidence, honesty, commercial ethics, risk taking, innovativeness, creativity, sociability, independent decision making, stress/uncertainty tolerance, need for autonomy, being consistent and principled.

Çetinkaya Bozkurt and Alparslan (2013) made a research on a sample of students about entrepreneurship traits. The major traits identified in this research are as the following: self-confidence, honesty, risk taking, and innovativeness.

Pirnar (2015) found that, tourism industry entrepreneurs differ from other industries' entrepreneurs. Accordingly, tourism entrepreneurs were likely to be highly motivated with life-style, quality of life (QOL) issues, locational preferences, and other non-economic motives. This research's data analysis indicates that, the sector can change the traits of entrepreneurs. In other words, entrepreneurial traits can vary from sector to sector.

The entrepreneurial activity, and traits can be affected by environment, by the national characteristics, especially culture. However, Mongia (2013) achieved the result that, there is no statistically significant difference between the persistency and success levels of Norwegian entrepreneurs, living and operating in Norway, and living and operating in the United States of America (USA). Also, the scholar also demonstrated that, low risk of tolerance does not affect the success levels of Norwegian entrepreneurs living and operating in Norway, or Norwegian entrepreneurs living and operating in USA. Mongia (2013) found that, Norwegian entrepreneurs in Norway have the same abilities to succeed as the entrepreneurs in the USA.

Kerr, Kerr and $\mathrm{Xu}$ (2017), pinpointed the heterogeneous nature of entrepreneurship in terms of the different views about its topics. The scholars examined the literature for the traits of Big-5 Model, self-efficacy and innovativeness, locus of control, and the need for achievement. The Big-5 Model includes (John, Naumann, Soto 2008): openness to experience, conscientiousness, extraversion, agreeableness, and neuroticism.

\section{The Methodology of the Field Research}

The field research was conducted on the participants of the entrepreneurship training programs in Giresun province of Turkey, in 2016 and 2017. The training programs which have a special name of "Basic Entrepreneurship Education" are realized under the coordination and control of Turkey's Small and Medium Sized Enterprises Development Organization (referred to as KOSGEB in Turkish). Each group consists of maximum 25 trainees.

The research was conducted via survey form, which included demographical and other questions. The survey form was developed by the researcher through the review of basic or most cited entrepreneurial characteristics in the literature. The participants were asked to choose five entrepreneurial traits which are the most important for them in the related processes.

The survey form was conducted on 480 participants. However, the 446 of them were found to be useful. Therefore, the sample of the research was 446. The universe of the research was the participants of official "Basic Entrepreneurship Training Programs", in Giresun province, Turkey, in the years of 2016, and 2017.

In the survey form, the participants were asked to choose five of the 23 possible traits of entrepreneurs.

The research was limited with the participants of "Basic Entrepreneurship Education" programs, which is a training program, in fact, in Giresun province, in the years of 2016, and 2017.

The research was made on the participants of entrepreneurship training programs. In other words, the field research was realized on the candidate entrepreneurs. Therefore, the characteristics of the sample also reflect the characteristics or the traits of the potential entrepreneurs. It can be estimated that, the findings about the participants' traits and views, also can be the reliable indicators of the traits of the active entrepreneurs.

The findings of the research also reflect the cultural characteristics of a society, which was associated by Hofstede (1980) with high levels of collectivism, power distance, uncertainty avoidance; and moderate feminity.

The following hypotheses were tested depending on the data analysis:

H1: There is a statistically significant relationship between the age of the respondents and their preference of best entrepreneurial traits.

$\mathrm{H} 2$ : There is a statistically significant association between the professions of the respondents and their preference of best entrepreneurial traits.

H3: The work experiences of respondents are statistically significantly associated with their best entrepreneurial trait preferences. 
H4: There is a statistically significant relationship between the number of children that the respondents have and the preference of respondents about the best traits of entrepreneurs.

H5: The thoughts on the best traits of entrepreneurs and the gender are statistically significantly associated.

H6: The participants' thoughts on the best traits of entrepreneurs, and the past business ownership of the participants are statistically significantly associated.

\section{Findings}

The findings of the field research are the followings.

Table 1. The Age of the Respondents

\begin{tabular}{|c|c|c|}
\hline $\begin{array}{c}\text { The } \\
\text { Age } \\
\text { Group }\end{array}$ & Frequency & Percentage \\
\hline $\begin{array}{c}18- \\
24\end{array}$ & 75 & 16.68 \\
\hline $\begin{array}{c}25- \\
30\end{array}$ & 125 & 28 \\
\hline $\begin{array}{c}31- \\
35\end{array}$ & 96 & 21.6 \\
\hline $\begin{array}{c}36- \\
40\end{array}$ & 73 & 16.3 \\
\hline $\begin{array}{c}41- \\
45\end{array}$ & 33 & 7.4 \\
\hline $\begin{array}{c}46- \\
50\end{array}$ & 18 & 4.1 \\
\hline $\begin{array}{c}51- \\
55\end{array}$ & 18 & 4.1 \\
\hline $\begin{array}{c}56- \\
60\end{array}$ & 6 & 1.4 \\
\hline $61-$ & 2 & 0.4 \\
65 & & 100 \\
\hline Total & 446 & \\
\hline 6
\end{tabular}

Table 1 demonstrates the age groups of the respondents. According to the table, 18-24 age group includes 75 individuals (16.68\%), 25-30 age group includes 125 individuals (28\%), 31-35 age group consists of 96 individuals $(21.6 \%), 36-40$ age group includes 73 individuals (16.3), 41-45 age group includes 33 individuals (7.4\%), 46-50 age group includes 18 individuals $(4.1 \%), 51-55$ age group includes 18 individuals $(4.1 \%), 56-60$ age group includes 6 individuals (1.4\%), 61-65 age group has 2 respondents $(0.4 \%)$. The sample was 446 .

Table 1 indicates that, the entrepreneurship training program mostly consists of the participants from the age group between $18-40(82.58 \%)$. This shows that, in the frame of the sample, mostly the individuals under age 40 have the tendency to initiate an entrepreneurial activity. It is in accordance with the conventional career terms in labour market. Accordingly, it can be claimed that, being an entrepreneur is an important choice for the young and even middle-aged individuals, in Giresun province, in Turkey. This situation has many different reasons: the high unemployment rate among youngsters (over 20\%), the weakness of another choice for employment, the opportunities for entrepreneurship, the opportunities that entrepreneurship presents, the desire for wealth, comfort in life, the tendency for independency, the financial supports of the state, and the popularity of entrepreneurship.

Table 2. The Gender of the Participants

\begin{tabular}{|l|c|c|}
\hline $\begin{array}{l}\text { The } \\
\text { Gender }\end{array}$ & Frequency & Percentage \\
\hline Women & 215 & 48.2 \\
\hline Men & 231 & 51.8 \\
\hline Total & 446 & 100 \\
\hline
\end{tabular}

The number of women in the sample was 215 which have the rate of $48.2 \%$. Accordingly, the number of men was 231 which have the rate of $51.8 \%$. In Turkey, the rate of the women entrepreneurs is relatively low. It is below the $10 \%$ of the total entrepreneur number in the country. So, the women entrepreneurship is especially supported by the Turkish Government. The women entrepreneurs are financially supported by the government with an extra amount compared with the men entrepreneurs. The Turkish State aims to increase the rate of women in the total number. The women entrepreneurs can be seen in any area of business in Turkey, but especially, they operate in food or catering business. "The home-made meals" are too popular in the country. These "home-made meal" businesses are generally owned by the women whose main profession is "housewife".

The rate of candidate women entrepreneurs in the sample can be an indicator of future balance or proportion between women and men in the area. It can be claimed that, the young and educated Turkish women might strengthen her position in business as entrepreneurs in coming years and decades.

Table 3. The Education Levels of Participants.

\begin{tabular}{|l|c|c|}
\hline \multicolumn{1}{|c|}{$\begin{array}{c}\text { Education } \\
\text { Level }\end{array}$} & Frequency & Percentage \\
\hline $\begin{array}{l}\text { Primary } \\
\text { School }\end{array}$ & 54 & 12.1 \\
\hline $\begin{array}{l}\text { Secondary } \\
\text { School }\end{array}$ & 50 & 11.2 \\
\hline $\begin{array}{l}\text { High } \\
\text { School }\end{array}$ & 164 & 36.8 \\
\hline $\begin{array}{l}\text { Bachelors' } \\
\text { Degree }\end{array}$ & 163 & 36.5 \\
\hline $\begin{array}{l}\text { Masters' } \\
\text { Degree }\end{array}$ & 15 & 3.4 \\
\hline PhD & 0 & 0 \\
\hline Total & 446 & 100 \\
\hline
\end{tabular}

Table 3 shows the education levels of the respondents. Accordingly, 54 of the respondents $(12.1 \%)$ are primary school graduates, 50 of the respondents are secondary school graduates (11.2\%), 164 of the respondents are high school respondents (\%36.8), 163 of them have the bachelor's degree, and 15 of them have the masters' degree. 
The data analyses indicate that, $39.9 \%$ of the respondents have the university degree. Again, 36.6 of them are the high school graduates. It is clear that, the majority of the respondents are educated. It can be maintained that, entrepreneurship is an important area for also educated people.

Table 4. The Existence of another Entrepreneur in the Family

\begin{tabular}{|l|c|c|}
\hline & Frequency & Percentage \\
\hline Yes & 153 & 34.3 \\
\hline No & 293 & 65.7 \\
\hline Total & 446 & 100 \\
\hline
\end{tabular}

The $34.3 \%$ of the participants (153) have another entrepreneur in the family. Thus, $65.7 \%$ of the respondents (293) do not have another entrepreneur in their family.

It is obvious that, the profession which the family members are familiar to, might have an impact on the preference of a job, or a career. So, $34.3 \%$ of the respondents have better opportunities to have information about entrepreneurship. Moreover, they can benefit from the experiences of the member who deals with entrepreneurship, in the family.

Table 5. The Family Members in Entrepreneurship

\begin{tabular}{|c|c|c|}
\hline Family Member & Frequency & Percentage \\
\hline Father & 30 & 6.7 \\
\hline Mother & 14 & 3.1 \\
\hline Brother/Sister & 37 & 8.3 \\
\hline Others & 74 & 16,6 \\
\hline Total & 155 & 34.7 \\
\hline
\end{tabular}

As it can be seen at Table 5, the frequency of the respondents that have an entrepreneur father is 30 , which represents the $6.7 \%$ of the total. Again, 14 of the respondents' $(3.1 \%$ of the sample) mother are entrepreneurs; 37 of the respondents' $(8.3 \%$ of the sample) brothers or sisters are entrepreneurs; and 74 of the respondents $(16.6 \%$ of the sample) have other relatives who are entrepreneurs. These numbers or rates worth attention for their possible similarity with the situation of real entrepreneurs.

The existence of an entrepreneur relative in the family can be a role model for other family members. On the whole, family members can learn from her or him; they can benefit from her or his experiences. So, to have an entrepreneur family member or a relative can trigger off the entrepreneurial behaviour.

Table 6. The Work Experience of Respondents

\begin{tabular}{|c|c|c|}
\hline $\begin{array}{c}\text { Work } \\
\text { Experience }\end{array}$ & Frequency & Percentage \\
\hline 0 & 92 & 20.6 \\
\hline $1-5$ & 147 & 33 \\
\hline $6-10$ & 84 & 18.9 \\
\hline
\end{tabular}

\begin{tabular}{|c|c|c|}
\hline $11-15$ & 52 & 11 \\
\hline $16-20$ & 40 & 8.9 \\
\hline $21-25$ & 9 & 2 \\
\hline $26-30$ & 11 & 2.4 \\
\hline $31-35$ & 6 & 1.2 \\
\hline $36-40$ & 3 & 0.6 \\
\hline $41+$ & 2 & 0.4 \\
\hline Total & 446 & 100 \\
\hline
\end{tabular}

The work experience of respondents has the following distribution: no work experience, 92 (20.6\%); 1-5 years, 147 (33\%); 6-10 years, 84 (18.9\%); 11-15 years, 52 (11\%); 16-20 years, 40 (8.9\%); 21-25 years, 9 (2\%); 2630 years, $11(2.4 \%)$; 31-35 years, $6(1.2 \%)$; 36-40 years, $3(0.6 \%)$; and $41+$ years, $2(0.4 \%)$. These data are in accordance with the ages of the respondents. It is clear that, inexperienced, or short time work experienced (1-5 years) respondents form the majority. It can be claimed that, entrepreneurship presents hope especially for the jobless, inexperienced or short-time work experienced individuals. This result is also associated with the ages of the same groups.

Table 7. Past Business Ownership

\begin{tabular}{|c|c|c|}
\hline $\begin{array}{c}\text { Past } \\
\text { Business } \\
\text { Ownership }\end{array}$ & Frequency & Percentage \\
\hline Yes & 79 & 17.7 \\
\hline No & 377 & 82.3 \\
\hline Total & 446 & 100 \\
\hline
\end{tabular}

Table 7 demonstrates the past ownership situation of respondents. Accordingly, 79 of the participants (17.7\%) established a business before, and 377 of the participants $(82.3 \%)$ did not establish a business before. To have a business ownership, or firm formation experience strengthens the entrepreneurs. Through the experience, they can avoid the same mistakes. Again, accumulated knowledge that originates from active experience supports creativity, and innovativeness. It is obvious that, the experiences of others can also be the source of knowledge, or information.

Table 9. Marital Status

\begin{tabular}{|c|c|c|}
\hline $\begin{array}{c}\text { Marital } \\
\text { Status }\end{array}$ & Frequency & Percentage \\
\hline Married & 265 & 59.4 \\
\hline Single & 181 & 40.6 \\
\hline Total & 446 & 100 \\
\hline
\end{tabular}

As it is shown at Table 9, the 265 of the respondents are married (59.4\%), and 181 of them are single (40.6\%). Marital status can be a factor in risk taking. 
Table 10. Number of Children

\begin{tabular}{|c|c|c|}
\hline $\begin{array}{c}\text { Number } \\
\text { of } \\
\text { Children }\end{array}$ & Frequency & Percentage \\
\hline 0 & 198 & 44.4 \\
\hline 1 & 91 & 20.4 \\
\hline 2 & 91 & 20.4 \\
\hline 3 & 50 & 11.2 \\
\hline 4 & 12 & 2.7 \\
\hline 5 & 1 & 0.2 \\
\hline 7 & 1 & 0.2 \\
\hline 9 & 1 & 0.2 \\
\hline 13 & 1 & 0.2 \\
\hline Total & 446 & 100 \\
\hline
\end{tabular}

To have a child, or children can have psychological effects on entrepreneurship, especially in risk taking. As Table 10 indicates, 198 (44.4\%) of the respondents do not have a child. 91 of the respondents $(20.4 \%)$, have one child; again, 91 of them $(20.4 \%)$ have two children. Moreover, 50 of the respondents $(11.2 \%)$ have three children; 12 of the respondents $(2.7 \%)$ have four children; 1 of the respondents $(0.2 \%)$ has five children. Similarly, same number and ratio $(1 ; 0.2)$ of respondents have seven, nine, and thirteen children, respectively.

Table 11. Age Related Correlation Analysis Results 1

\begin{tabular}{|c|c|c|c|c|c|}
\hline & D1 & D13 & D14 & D25 & D17 \\
\hline D1 & 1 & $\begin{array}{l}.104^{*} \\
.028 \\
\end{array}$ & $\begin{array}{l}.073 \\
.122 \\
\end{array}$ & $\begin{array}{c}.154 * * \\
.001 \\
\end{array}$ & $\begin{array}{l}-.016 \\
.742 \\
\end{array}$ \\
\hline D13 & $\begin{array}{l}.104 * \\
.028\end{array}$ & 1 & $\begin{array}{c}-.108 * \\
.022\end{array}$ & $\begin{array}{l}.079 \\
.994\end{array}$ & $\begin{array}{l}.085 \\
.072\end{array}$ \\
\hline D14 & $\begin{array}{l}.073 \\
.122\end{array}$ & $\begin{array}{l}- \\
.108 * \\
.022 \\
\end{array}$ & 1 & $\begin{array}{l}-.076 \\
.110\end{array}$ & $\begin{array}{c}- \\
.153 * * \\
.001\end{array}$ \\
\hline D25 & $\begin{array}{l}.154 * * \\
.001\end{array}$ & $\begin{array}{l}.079 \\
.094\end{array}$ & $\begin{array}{l}-.076 \\
.110\end{array}$ & 1 & $\begin{array}{c}- \\
.216^{* *} \\
.000\end{array}$ \\
\hline D17 & $\begin{array}{l}-.016 \\
.742\end{array}$ & $\begin{array}{l}.085 \\
.072\end{array}$ & $\begin{array}{c}- \\
.153 * * \\
.001 \\
\end{array}$ & $\begin{array}{c}- \\
.216 * * \\
.000\end{array}$ & 1 \\
\hline
\end{tabular}

(** Correlation is significant at the 0.01 level; * Correlation is significant at the 0.05 level.) (2-tailed). (D1: The ages of the respondents ; D13: self-confidence; D14: innovativeness; D25: honesty; D17: risk taking.).

Table 11 demonstrates the correction results with the age of the respondents and their prior preference for entrepreneurial traits. Accordingly, there is only a low level correlation between the age and some of the traits: self-confidence $(.104 ; .028)$; honesty $(.154 ; .742)$. Thus, $\mathrm{H} 1$ is partially accepted.

Table 12. Profession-Rel. Correlation Analyses Results 2

\begin{tabular}{|l|l|l|c|c|c|}
\hline & D6 & D13 & D14 & D25 & D17 \\
\hline D6 & 1 & -.013 & .018 & -.052 & .074 \\
& & .789 & .698 & .275 & .121 \\
\hline
\end{tabular}

(** Correlation is significant at the 0.01 level; * Correlation is significant at the 0.05 level.) (2-tailed). (D6: The profession of the respondents; D13: self-confidence; D14: innovativeness; D25: honesty; D17: risk taking.).

Table 12 presents the profession related correlation analyses results. It can be seen from the table that, there are no links between the profession of the respondents and their preference for entrepreneurial traits. So, H2 is rejected.

Table 13. Experience-Rel. Correlation Analyses Res. 3

\begin{tabular}{|l|l|l|l|l|l|}
\hline & \multicolumn{1}{|c|}{ D7 } & D13 & D14 & D25 & D17 \\
\hline D7 & 1 & .056 & .025 & .030 & .006 \\
& & .241 & .599 & .533 & .895 \\
\hline
\end{tabular}

(** Correlation is significant at the 0.01 level; * Correlation is significant at the 0.05 level.) (2-tailed). (D7: The work experince of respondents; D13: self-confidence; D14: innovativeness; D25: honesty; D17: risk taking.).

As it can be seen at table 13, the work experience of respondents is not associated with the best entrepreneurial trait preferences of respondents. Hence, H3 is rejected.

Table 14. Number of Children - Correlation Analyses

\begin{tabular}{|l|l|l|c|c|c|}
\hline & D11 & D13 & D14 & D25 & D17 \\
\hline D11 & 1 & $.183^{* *}$ & .080 & $.165^{* *}$ & - \\
& & .000 & .093 & .000 & .059 \\
& & & & & .210 \\
\hline
\end{tabular}

(** Correlation is significant at the 0.01 level; * Correlation is significant at the 0.05 level.) (2-tailed). (D11: The number of children; D13: self-confidence; D14: innovativeness; D25: honesty; D17: risk taking.).

Table 14 demonstrates the correlation between the number of children of the respondents and the preference of the about the best traits of entrepreneurs. Accordingly, there is a statistically significant relationship between the number of children of respondents, and their preferences of traits self-confidence $(.183 ; .000)$, honesty $(.165 ; .000)$. Therefore, H4 is partially accepted.

Table 15. The Mann-Whitney U Test Results on the Gender and Preferences of the Best Entrepreneurial Traits

\begin{tabular}{|l|c|l|c|c|c|}
\hline Gender & N & $\begin{array}{c}\text { Mean } \\
\text { Rank }\end{array}$ & $\begin{array}{c}\text { Sum of } \\
\text { Ranks }\end{array}$ & $\begin{array}{c}\text { Mann } \\
\text { Whitney } \\
\text { U }\end{array}$ & Sig. \\
\hline Female & 215 & 237.1 & 50975.5 & 21694.5 & .001 \\
\hline Male & 231 & 209.82 & 48259.5 & & \\
\hline
\end{tabular}

Table 15 shows the Mann-Whitney U Test results pertaining the relationship between the participants' thoughts on the best traits of entrepreneurs, and the gender. According to these test results, there is a statistically significant relationship between the thoughts on the best traits of entrepreneurs, and the gender within 
the sample group (21694.5; sig. <0.05). Therefore, H5 is accepted.

Table 16. The Mann-Whitney U Test Results on the Past Business Ownership and Preferences of the Best Entrepreneurial Traits

\begin{tabular}{|l|c|c|c|c|c|}
\hline $\begin{array}{l}\text { Past } \\
\text { Business } \\
\text { Ownership }\end{array}$ & N & $\begin{array}{l}\text { Mean } \\
\text { Rank }\end{array}$ & $\begin{array}{l}\text { Sum of } \\
\text { Ranks }\end{array}$ & $\begin{array}{c}\text { Mann } \\
\text { Whitney } \\
\text { U }\end{array}$ & Sig. \\
\hline Yes & 216 & 221.48 & 47396.5 & 24391.5 & .667 \\
\hline No & 230 & 223.45 & 51393.5 & & \\
\hline
\end{tabular}

Table 16 shows the Mann-Whitney U Test results pertaining the relationship between the participants' thoughts on the best traits of entrepreneurs, and the past business ownership of the participants. According to these test results, there is no statistically significant relationship between the thoughts on the best traits of entrepreneurs, and the business ownership within the sample group (21694.5; sig. >0.05). Therefore, H6 is not accepted.

Table 17. The Entrepreneurial Traits

\begin{tabular}{|l|l|l|c|}
\hline & & \multicolumn{1}{|c|}{ Name of the Trait } & \multicolumn{2}{l|}{ Frequency } \\
\cline { 3 - 4 } & & & \\
\hline 1. & 13 & Self-Confidence & 373 \\
\hline 2. & 14 & Innovativeness & 235 \\
\hline 3. & 25 & Honesty & 221 \\
\hline 4. & 17 & Risk taking & 166 \\
\hline 5. & 22 & Ability for marketing & 145 \\
\hline 6. & 19 & Sense of responsibility & 132 \\
\hline 7. & 20 & Leadership & 115 \\
\hline 8. & 27 & Creativity & 103 \\
\hline 9. & 35 & Determination & 102 \\
\hline 10. & 30 & Utilize the opportunities & 89 \\
\hline 11. & 24 & Communication skill & 85 \\
\hline 12. & 23 & Managerial skill & 84 \\
\hline 13. & 36 & Knowledge & 84 \\
\hline 14. & 26 & Social being & 54 \\
\hline 15. & 29 & Consistency and to be & 49 \\
\hline 16. & 34 & Being ambitious & 6 \\
\hline 17. & 21 & Competitiveness & 40 \\
\hline 18. & 16 & Internal locus of control & 31 \\
\hline 19. & 15 & Achievement need & 30 \\
\hline 20. & 28 & Independent decision making & 17 \\
\hline 21. & 31 & Change focus & 14 \\
\hline 22. & 33 & Emotional intelligence & 10 \\
\hline 23. & 32 & Proactivity & 6 \\
\hline 24. & 15 & Flexibility against uncertainty & 3 \\
\hline & & & \\
\hline
\end{tabular}

As it can be seen in Table 17, the frequency of the characteristics are as the following: self-confidence, 373; innovativeness, 235; honesty, 221; risk taking, 166, ability for marketing, 145; sense of responsibility, 132; leadership, 115; creativity, 103; determination, 102; utilizing the opportunities, 89; communication skill, 85; managerial skill, 84; knowledge, 84; social being, 54; consistency and to be principled, 49; being ambitious, 40; competitiveness, 36; internal locus of control, 31; achievement need, 30; independent decision making, 17; change focus, 14; emotional intelligence, 10; proactivity, 6; and flexibility against uncertainty, 3 .

The top five characteristics for entrepreneurs chosen by the participants are self-confidence, innovativeness, honesty, risk taking, and ability for marketing. These traits are the base for an entrepreneurial behaviour, and an entrepreneurial initiative. It is clear that, the participants of entrepreneurship training programs in Turkey, identify the best traits for entrepreneurs. These traits are generally accepted as "the keys" for a successful entrepreneurship.

\section{Conclusions}

This study has investigated the possible traits of entrepreneurs depending on a research which was conducted on the participants of official entrepreneurship training programs. Accordingly, this study has shown that, the basic traits that are assumed to be linked with the entrepreneurs are self-confidence, innovativeness, honesty, risk taking, and ability for marketing. This study also demonstrated that, the sense of responsibility, leadership, creativity, determination, and utilizing the opportunities are the next five key traits for entrepreneurs. On the other hand, "independent decision making", "change focus", emotional intelligence, proactivity, and "flexibility against uncertainty" are the least chosen five traits linked with entrepreneurship.

The data analysis has also shown that, there is an association between the age of the respondents, and their preferences about the best traits of entrepreneurs. Again, he number of children, and the preference of the best traits of entrepreneurs are correlated. However, no links were identified between the profession of the respondents and their preference of best entrepreneurial trends. Similarly, the work experience of participants, and the preferred entrepreneurial best traits are not associated, in the frame of the sample group. Moreover, it was identified that, the past business experiences do not have an impact on the preferences; as a result which is out of expectations.

The data analysis demonstrated the link between the gender, and the distribution of entrepreneurial best trait differences. The gender can be a key point in terms of different approaches for different dimensions, or variables. It is clear that, different experiences result in different approaches. In addition, the differences in physiology can also result in the different approaches to events.

These results are achieved in Turkish culture which was linked by Hofstede (1980) with high levels of collectivism, power distance, and uncertainty avoidance; and a moderate feminity. However, the similarities between the findings of this research and the literature can be related with the survey form which creates a framework. Again, the integration of cultures and economies result in common perspectives. So, the similarities of findings with the literature can be explained from this point of view.

The future studies should focus on the differences of entrepreneurial traits between the cultures. 


\section{References}

Action Coach (2020). 12 Essential Characteristics of an Entrepreneurhttps://www.business.com/images/content/58a/d9f1f2f 87b1207f720c3d/0-0-/

Abdulwahab, M. H., Al-Damen, R. A. (2015). The Impact of Entrepreneurs' Characteristics on Small Business Success at Medical Instruments Supplies Organizations in Jordan. International Journal of Business and Social Science, 6(8), 164175. http://ijbssnet.com/journals/Vol_6_No_8_August_2015/17.pdf

Ağca, V., Kurt, M. (2007). İç Girişimcilikte Temel Belirleyicileri: Kavramsal Bir Çerçeve. Erciyes Üniversitesi İktisadi ve İdari Bilimler Fakültesi Dergisi, 29, 83-112.

Aytaç, Ö., İlhan, S. (X). Girişimcilik ve Girişimci Kültür: Sosyolojik Bir Perspektiv.

Ballı, A. (2017). Girişimci ve Girişimci Tipolojileri. Süleyman Demirel Üniversitesi Sosyal Bilimler Enstitüsü Dergisi, 4(29), 143-166. http://sbedergi.sdu.edu.tr/assets/uploads/sites/343/files/29-sayiyazi6-08092018.pdf

Baron, R. A. (1998). Cognitive Mechanisms in Entrepreneurship: Why and When Entrepreneurs Think Differently than Other People. Journal of Business Venturing, 13(4), 275-294.

Baron, R. A. (2004). The Cognitive Perspective: A Valuable Tool for Answering Entrepreneurship's Basic Why Question. Journal of Business Venturing, 19(2), 221-229.

Beaver, G. (2002). Small Business, Entrepreneurship, and Enterprise Development. Pearson Education Limited, England.

Becker, G. S. (1975). Human Capital. The National Bureau of Economic Research, Second Edition, United States of America.

Corbett, A. C., Hmieleski, K. M. (2005). How Corporate Entrepreneurs Think: Cognition, Context, and Entrepreneurial Scripts. Academy of Management Best Conference Paper, D1-D7.

Çetinkaya Bozkurt, Ö. (2011). Dünya'da ve Türkiye'de Girişimcilik Eğitimi: Başarılı Girişimciler ve Öğretim Üyelerinden Öneriler. Detay Yayıncılık, Ankara, Turkey.

Çetinkaya Bozkurt, Ö., Kalkan, A., Koyuncu, O., Alparslan, A. M. (2012). Türkiye'de Girişimciliğin Gelişimi: Girişimciler Üzerinde Nitel Bir Araștırma. Süleyman Demirel Üniversitesi Sosyal Bilimler Enstitüsü Dergisi, $\quad 1(15), \quad 229-247$. http://dergipark.org.tr/en/download/article-file/215810

Çetinkaya Bozkurt, Ö. (2013). Girişimcilerde Bulunması Gereken Özellikler ve Girişimcilik Eğitimi: Girişimci ve Öğrenci Görüşleri. Girişimcilik ve Kalkınma Dergisi, 8:13, 7-29. http://www.acarindex.com/dosyalar/makale/acarindex1423881603.pdf

Daft, R. L. (2005). The Leadership Experience. Third Edition, Thomson South-Western College Publishing, Canada.

Drucker, P. F. (1998). The Discipline of Innovation. Harvard Business Review, 76(6), 149-160. https://hbr.org/2002/08/the-discipline-ofinnovation

Chuluunbaatar, E. O., Luh, D. (2010). Entrepreneurship Start-up Process: The Role of Emotional Intelligence. International Conference on Kansei Engineering and Emotion Research, March 2-4 Paris.

Gartner, W. B. (1988). Who is an Entrepreneur? Is the Wrong Question? American Journal of Small Business, 12(4), 11-32.

Geisler, E. (1993). Middle Managers and Internal Corporate Entrepreneurs: An Unfolding Agenda. Interfaces, 23(6), 52-63. https://www.jstor.org/stable/pdf/25061821.pdf

Güney, S. (2006). Kadın Girişimciliğine Genel Bir Bakış. Girişimcilik ve Kalkınma Dergisi, 1(1), 25-44.

Hatten, T. S. (1997). Small Business: Entrepreneurship and Beyond. Prentice-Hall, Inc., Unites States of America.

Herron, L. (1992). Cultivating Corporate Entrepreneurs. Human Resource Planning, 15(4), 3-14.

Hewison, A., Badger, F. (2006). Taking the Initiative: Nurse Intrapreneurs in the NHS. Nursing Management-UK, 13(3), 14-19.

Hisrich, R. D., Peters, M., Shepherd, D. A. (2005). Entrepreneurship. $6^{\text {th }}$ Edition. McGrawHill, New York, USA.

Hitt, M. A., Black, S., Porter, L. W. (2005). Management. International Edition. Pearson Prentice-Hall, New Jersey, USA.

Hofstede, G. (1980). Culture's Consequences: International Differences in Work-Related Values. Sage Publications, United States of America.

John, O. P., Naumann, L. P., Soto, C. J. (2008). Paradigm Shift to the Integrative Big Five Trait Taxonomy: History, Measurement, and Conceptual Issues. In O. P. John, R. W. Robins, L. A. Pervin (Eds.). Handbook of Personality: Theory and Research. Guildford Press, New York, 114-158.
Kerr, S. P., Kerr, W. R., Xu, T. (2017). Personality Traits of Entrepreneurs: A Review of Recent Literature. Working Paper: 18047. Harvard Business School. https://www.hbs.edu/faculty/publication\%20files/18047_b0074a64-5428-479b-8c83-16f2a0e97eb6.pdf

Kerr, S. P., Kerr, W. R., Xu, T. (2018). Personality Traits of Entrepreneurs: A Review of Recent Literature. Foundations and Trends in Entrepreneurship, 14 (3).

Kozubikova, L. Dvorsky, J., Cepel, M., Balcerzak, A. P. (2017). Important Characteristics of an Entrepreneur in Relation to Risk Taking: Czech Republic Case. Journal of International Studies, $10(3)$,

220-233. https://www.jois.eu/files/15_412_Kozubikova\%20et\%20al.pdf

Lachman, R. (1980). Toward Measurement of Entrepreneurial Tendencies. Management International Review, 20(2), 108-116.

Lee, J. (1999). Impact of Culture on Entrepreneurship. AAM Journal, 42(2), 1-22

Luchsinger, V. P., Bagby, D. R. (1987). Entrepreneurship and Intrapreneuship: Behaviors, Comparisons, and Contrasts. SAM Advanced Management Journal, 52(3), 10-13.

Marx, K. (1867). Das Kapital. Yordam Yayınevi, Istanbul, Turkey, 2018.

Megginson, W. L., Byrd, M. J., Megginson, L. C. (2000). Small Business Management: An Entreppreneur's Guide Book. Irwin McGraw-Hill, USA.

Mills J, Clark M. S. (1982). Exchange and communal relationships. Personality and Social Psychology, 3, 121-144. Editor L. Wheeler. Sage, United States of America.

Mitchel, R. K., Busenitz, L., Lant, T., McDougall, P. P., Morse, E. A., Smith, B. J. (2002). Toward a Theory of Entrepreneurial Cognition: Rethinking the People Side of Entrepreneurial Research. Entrepreneurship: Theory and Practice, 27(2), 93-104.

Mongia, A. K. (2013). Characteristics and Attitudes of Successful Entrepreneurs. Unpublished Masters' Thesis, Norwegian University of Science and Technology (NTNU - Trondheim). https://core.ac.uk/download/pdf/52109007.pdf

Nair, K. R. G., Pandey, A. (2006). Characteristics of Entrepreneurs: An Ampirical Analysis. The Journal of Entrepreneurship, 15(1). Sage Publications. https://journals.sagepub.com/doi/pdf/10.1177/09713557050150010 4

Okhomina, D. (2010). Entrepreneurial Orientation and Psychological Traits: The Moderating Influence of Supportive Environment. Journal of Behavioural Studies in Business. https://www.researchgate.net/publication/242748294_Entrepreneuri al_orientation_and_psychological_traits_the_moderating_influence _of_supportive_environment

Parnell, H. A., Crandall, W. R., Menefee, M. (1995). Examining the Impact of Culture on Entrepreneurial Propensty: An Empirical Study of Prospective American and Eygptian Entrepreneurs. Academy of Entrepreneurial Journal, 1(1), 39-53.

Pirnar, I. (2015). The Specific Characteristics of Entrepreneurship Process in Tourism Industry. Selçuk Üniversitesi Sosyal Bilimler Enstitüsü Dergisi, 34, 75-86.

Salamzadeh, A., Farjadian, A. A., Amirabadi, M., Modarresi, M. (2014). International Journal of Entrepreneurship and Small Business, 21(2), 165-182.

Tiftik, H., Zincirkiran, M. (2014). A Survey of Entrepreneurial Tendencies Candidate Young Entrepreneurs: Foundation University Sample. Journal of Management Research, 6(2), 177-200.

Tiryaki, A. (2012). İktisat Teorisinde Girişimcilik. Girişimcilik ve KOBİLER: Kavramlar, Sorunlar ve Çözüm Önerileri. Erdoğan, Z. (Edt.), Ekin Yayınevi, Bursa.

Triandis, H.C., Gelfand, M. J. (1998). Converging measurement of horizontal and vertical individualism and collectivism. Journal of Personality and Social Psychology. 74(1), 118-128.

Uygun, R. K. (2016). Girişimcilik Teori ve Uygulamaları. Birinci Bask1, Ekin Yayınevi, Bursa, Turkey.

Yelkialan, N. (2006). Başarılı Girişimcilikte Cinsiyetin Rolü: Kadın ve Girişimciler. Girişimcilik ve Kalkınma Dergisi, 1(1), 45-54.

Yüceol, N. (2018). Girişimcilik Eğitimi Alan Kişilerin Girişimci Kişilik Özellikleri ve Girişimcilik Eğilimi Arasındaki İlişki Üzerine Bir Araştırma. Unpublished Masters' Thesis, Istanbul Gelişim University, Turkey.

Westhead, P., Ucbasaran, D., Wright, M. (2003). Differences between Private Firms Owned By Novice, Serial and Portfolio Entrepreneurs: Implications for Policy Makers and Practitioners. Regional Studies, 37(2), 187-200. 
Zhao, H., Seibert, S. E., Hills, G. E. (2005). The Mediating Role of SelfEfficacy in the Development of Entrepreneurial Intentions. Journal of Applied Psychology, 90(6), 1265-1272. https://psycnet.apa.org/fulltext/2005-14549-017.pdf

Zakarevicius, P., Zuperka, A. (2010). Expression of Emotional Intelligence in Development of Students' Entrepreneurship.
Economics and Management, 15, 865-873. https://www.vdu.lt/cris/handle/20.500.12259/49240

Kurtuluş Yılmaz Genç (PhD), is an associate professor of management at Giresun University of Turkey. He gained his bachelor's degree from Ankara University, masters' and $\mathrm{PhD}$ degrees from Karadeniz Technical University of Turkey. His research areas are strategic management, human resource management, entrepreneurship, management history, and environmental management. Adress: Giresun Universites Iktisadi ve Idari Bilimler Fakültesi, Giresun, Turkey. E-mail: kyilmazgenc@gmail.com 